\title{
FORMULATION FOR DEVELOPMENT OF LOW-COST SILVICULTURAL MODEL FOR PRODUCTION FOREST IN ACEH PROVINCE, INDONESIA
}

\author{
Mahyuddin¹, Abubakar Karim², Sugianto², Ashabul Anhar ${ }^{3}$ \\ ${ }^{1}$ Faculty of Agriculture, Universitas Syiah Kuala, Banda Aceh 23111, Indonesia \\ ${ }^{2}$ Department of Soil Science, Faculty of Agriculture, Universitas Syiah Kuala, Banda Aceh 23111, Indonesia \\ ${ }^{3}$ Department of Forestry, Faculty of Agriculture, Universitas Syiah Kuala, Banda Aceh 23111, Indonesia
}

Link to this article: https://doi.org/10.11118/actaun.2021.047

Received: 19. 1. 2021, Accepted: 13. 7. 2021

To cite this article: MAHYUDDIN, KARIM ABUBAKAR, SUGIANTO, ANHAR ASHABUL. 2021. Formulation for Development of Low-Cost Silvicultural Model for Production Forest in Aceh Province, Indonesia. Acta Universitatis Agriculturae et Silviculturae Mendelianae Brunensis, 69(4): 519-531.

\begin{abstract}
Production forest is a forestry area used to produce forest products through Business Permit for Timber Forest Products Utilization (locally known as IUPHHK). Today, the main problems in the production forest industry management system are that the developed silvicultural system is still high in cost, and the mechanism of forest supervision and maintenance does not involve the forest communities. Therefore, it is necessary to make an effective and efficient design of a low-cost silvicultural model for production forests to be implemented in Aceh Province. This research aims to generate a low-cost silvicultural model for production forest in Aceh Province with a system approach using soft systems methodology (SSM). This research resulted in a low-cost silvicultural conceptual model for production forest and intervention strategies to be implemented by stakeholders to achieve the goals. Generally, the implementable intervention form is to develop synergy and partnership between the forest community and the IUPHHK-holder company in production forest management to run some production activities such as plantation process, security, and supervision. Moreover, participatory enhancement is necessary from the main actors: the government, the IUPHHK holder company, and the community by carrying out their duties and responsibilities according to their respective proportions.
\end{abstract}

Keywords: CATWOE, production forest, IUPHHK, conceptual model, soft system methodology

\section{INTRODUCTION}

Indonesia is one of the countries with the largest tropical forest in the world (Barber et al., 2002), this certainly will have a lot of positive impact on Indonesia because the presence of tropical forest has an important role in the provision of timber resources, the survival of germplasm, source of natural medicine ingredients, also its role as a provider of environmental services, such as regulation of water availability, prevention of erosion, control of climate patterns, and role as a carbon sink (Fearnside and Guimaraes, 1996;
Chazdon and Coe, 1999; Sujarwo and Darma, 2011; Suwardi et al., 2013). However, on the other side, deforestation keeps happening throughout the year, it is seen that in 1997, the level of deforestation in Indonesia was around 800,000-900,000 ha per year, and in 2001, it increased to 1.8 million ha per year, and then in 2003/2004, the rate of deforestation had reached 3.8 million ha per year (Nugraha, 2004; Darmanto, 2014). The same thing is also presented by The World Bank data, wherein 2006, the forest area in Indonesia had shrunk by 10\% (The World Bank, 2009). 
The management of forests becomes a current central-global issue, especially when there is awareness regarding global warming and the increase in the amount of carbon monoxide in the air. Besides maintaining the earth's climate, the forest can also be utilized for its economic potential if it is properly managed. Legal utilization of forest in Indonesia needs Business Permit for Timber Forest Products Utilization (IUPHHK); this policy is written in the Regulation of Minister of Forestry of the Republic of Indonesia Number P.50/Menhut-II/2010 and had been changed into number P.26/Menhut-II/2012 regarding Procedures for Granting and Expansion of Working Area of Business Permit for Timber Forest Products Utilization (IUPHHK) and Natural Forest. The target for the development of plantation forest until 2030 is 15.9 million hectares for Industrial Plantation Forest (locally known as HTI) and 2.6 million hectares for Community Plantation Forest (locally known as HTR) (KLHK, 2020).

Forest management is very important to do to maintain the continuity of the forest ecosystem. Sustainable forest management is forest management that follows the principles of sustainable development with social, economic, and environmental goals (HB, 2014). Sustainable forest management is a forest management process that implements the principle of balance between forest economic and ecological functions. This principle of balance is performed to achieve continuity of production characterized by continuous forest production without causing depreciation and decreased productivity and other impacts that harm the physical and social environment. Also, without causing other impacts that will harm the forest environment in the future (ITTO, 1992; Panyugallo, 2010).

Aceh Province has a forestry area up to 3,557,928 ha, which from that number, the area of fixed production forest is by 554,339 ha or $15.6 \%$ from the total area, whereas the area of limited production forest is by 141,771 ha or $3.9 \%$ from the total forest area, and the convertible production forest is by 15.409 ha. Bireuen Regency is one of Aceh Province's regencies, which has an area of production forest by 31,151.98 ha. These forest areas are scattered on the south side of the Bireuen Regency, which are in Samalanga, Simpang Mamplam, Pandrah, Jeunieb, Peulimbang, Peudada, Juli, Peusangan Selatan, Peusangan Siblah Krueng, and Makmur Districts. Besides, there are also production forest areas by $32,180.45$ ha and limited production forest 3,999.11 that are scattered in the south side of Bireuen Regency, which are in Peulimbang and Peudada Districts (BPS Bireuen, 2016). From those total areas, it is estimated that $4 \%$ of them have been deforested, unproductive, and have not been granted management rights (Widiyanto et al., 2012).

Thus far, the main problems in the management system of production forests are that the developed silvicultural system is still high in cost. The mechanism of forest supervision and maintenance does not involve the forest communities themselves. Moreover, Darusman and Bahruni (2004) stated that the sustainable forest's production cost is higher than unsustainable forest. The increased production cost of the sustainable forest is ranged between $\$ 18-30 \mathrm{USD} / \mathrm{m}^{3}$. Another problem is that the participation of local communities in the management system of production forest is still low, whereas community participation is one of the factors that greatly influence the success of sustainable forest management (Novayanti et al., 2017). Forest management that does not involve the community can potentially lead to a conflict of forest management. This conflict has commonly happened between the local community with the forest management (either from government or private institutions) or among the community itself. The conflict can directly affect the corporate financial stability and the continuity of environmental sustainability, either physical or non-physical (Margiawaty, 2004).

According to those problems, in order to manifest integrated and sustainable management of production forest in Aceh Province-Indonesia, it needs an effective and efficient development formulation of a low-cost silvicultural model for production forest. This model is expected to generate a silvicultural system for production forest that has low production cost by developing technical and institutional aspects by involving local communities around the production forest. To design that model, a soft system methodology (SSM) approach is used. Soft systems methodology is a holistic approach to seeing real and conceptual aspects in the community. This method has been used as one of the strategies in solving various managerial problems that grow from the human activity system (Bergvall-Kareborn, 2002; Martin, 2008; Fadhil et al., 2017). Soft system methodology has been widely used to solve several problems that grow in the community in many fields of the problem (Fadhil et al., 2018).

The purpose of this study is to formulate the development of a low-cost silvicultural model for production forests with a systems approach using soft systems methodology (SSM). The result of this study is expected to be able to contribute in generating formulation of the development of a low-cost silvicultural model for production forest by taking the case of modeling in Aceh Province in the form of intervention strategy which is able to be applied in order to manifest integrated and sustainable management of production forest. This study is also expected to increase positive impacts towards forest ecology, increase company profits, and increase the community's welfare around production forest. 


\section{MATERIALS AND METHODS}

The data used in this research are primary and secondary data. Primary data were obtained through direct observation of the area of Peusangan production forest, Bireuen Regency, Aceh Province, Indonesia (Fig. 1). Besides, to gain accurate information, data collection was carried out through interviews, questionnaires, and discussions with the experts. The experts involved in the research are a group of farmers using products of Alue Simantoek forest, Forest Management Unit Section (Bagian Kesatuan Pengelolaan Hutan/BKPH) of Meureudu, Forest Management Unit (locally known as Kesatuan Pengelolaan Hutan/KPH) Zone II of Aceh Province, Forest Management Resort (locally known as Resort Pengelolaan Hutan/RPH) of Ulee Gle, Production Forest Management Office (locally known as Balai Pengelolaan Hutan Produksi/BPHP) Zone I of Banda Aceh, Lecturer of Universitas Syiah Kuala (USK), forestry practitioners, Department of Environment and Forestry of Bireuen Regency, Headman of Hagu Village, and Headman of Lawang Village. Secondary data are data collected from current data and data from the previous year, obtained from a related institution or a literature study. These data are usually obtained from the Central Bureau of Statistics (locally known as BPS) of Aceh, BPS of Bener Meriah, BPS of Bireuen, and BPHP Zone I Banda Aceh.
Next, development formulation was done for a low-cost silvicultural model for production forest with a system approach using soft systems methodology (SSM) that was developed by Checkland and Poulter (2010) and Checkland (2013). There are seven steps done in the modeling using SSM (Fig. 2) (Checkland and Poulter, 2010; Darmanto, 2014; Batubara, 2016; Fadhil et al., 2017; Fadhil et al., 2018; Fakhrurrazi, 2018), which are:

1. Studying factual and actual problems of IUPHHK Peusangan potential area, either the area around the forest or forest potential on the area of Peusangan production forest, by collecting a number of actual information regarding the implementation of production forest management. In addition to actual information on the field, views and assumptions from involved parties have also become important information to consider. These data were obtained through field observation, interviews, discussion with experts, and the search of various information collected to obtain some developing information and thoughts.

2. All information, data, and problem situations obtained from the previous step were then expressed in the form of a rich picture, which represented the developing circumstances.

3. Make a formulation for root definition from the system related to the problem situation. This formulation was performed using a brief
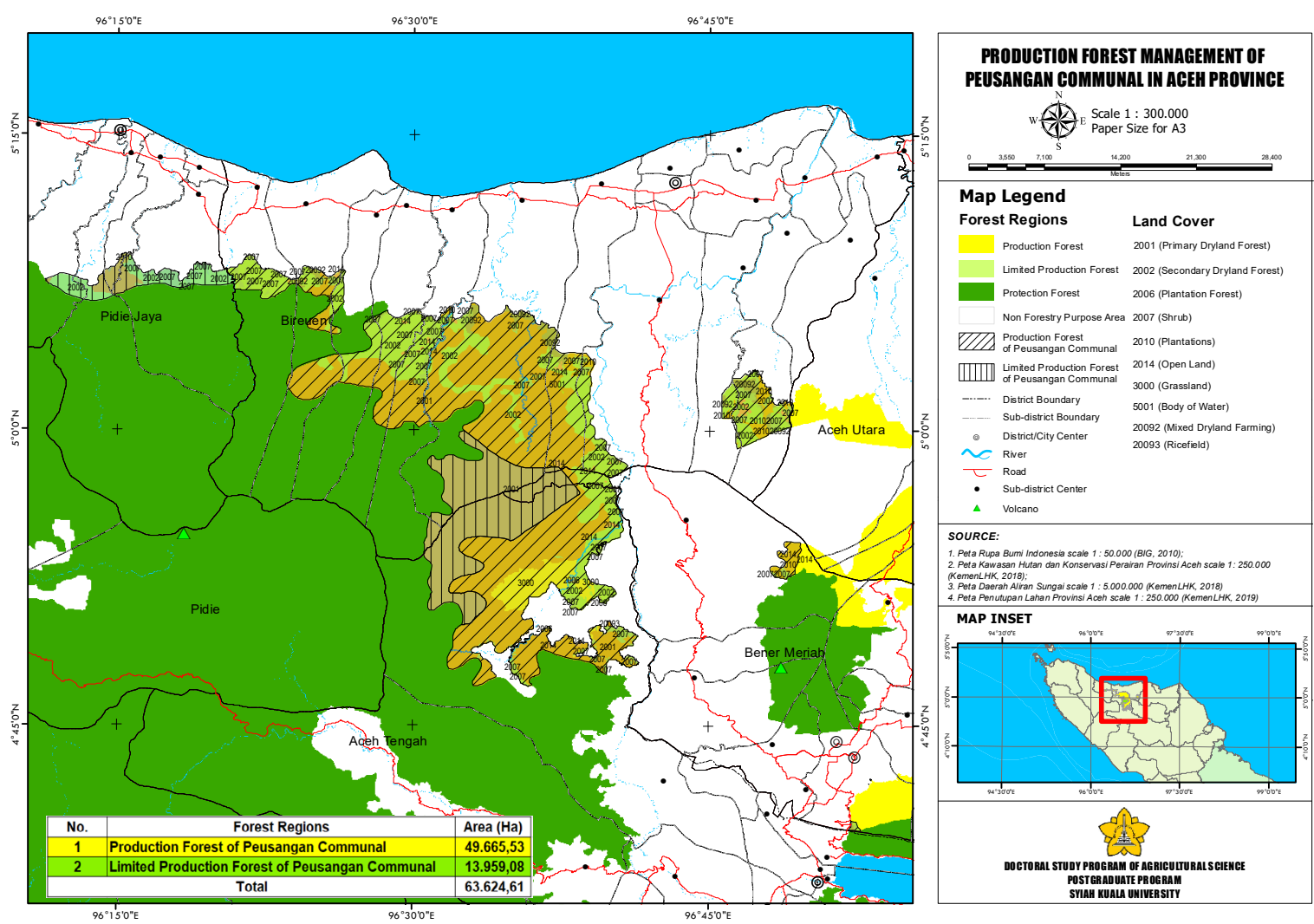

1: Area of Peusangan Forest that was used as the study area 
sentence that stated that "a system does P by Q to achieve R". This formula will answer the question of what, how, and why about the studied system. The root definition was then examined and enhanced with analysis aids CATWOE $(\mathrm{C}=$ customer, $\mathrm{A}=$ actors, $\mathrm{T}=$ transformation, $\mathrm{W}=$ world-view, $\mathrm{O}=$ owners, $\mathrm{E}=$ environmental constraint) as seen in Tab. I.

4. Develop a conceptual model. The result from the root definition was then made as a basis in the making of the conceptual model that is needed to achieve the ideal goal. The conceptual model can be defined as a set of logically structured activities in a notion system bounded by root definition.

5. Compare the conceptual model with the real world. The conceptual model that has been formed was then compared with the real-world to highlight the probability of changes in the real world. The purpose of this step is to mark the difference between the actual situation with the perceived reality. The involved participants were given the freedom to rethink their assumptions, either to be defended or to be revised.

6. Define the expected changes. In this step, identification was carried out towards the result obtained from the previous step to systematically and feasibly find the expected changes.

7. Formulate the changes to fix the condition. This is a step to carry out all of the resulted recommendations of changes to manifest integrated and sustainable management of production forest in Aceh Province, so that it can increase positive impact for the forest ecology and the welfare of the community around the production forest.

\section{RESULTS AND DISCUSSION}

\section{Situational Analysis}

The forest management model is one of the main factors that determine the continuity of

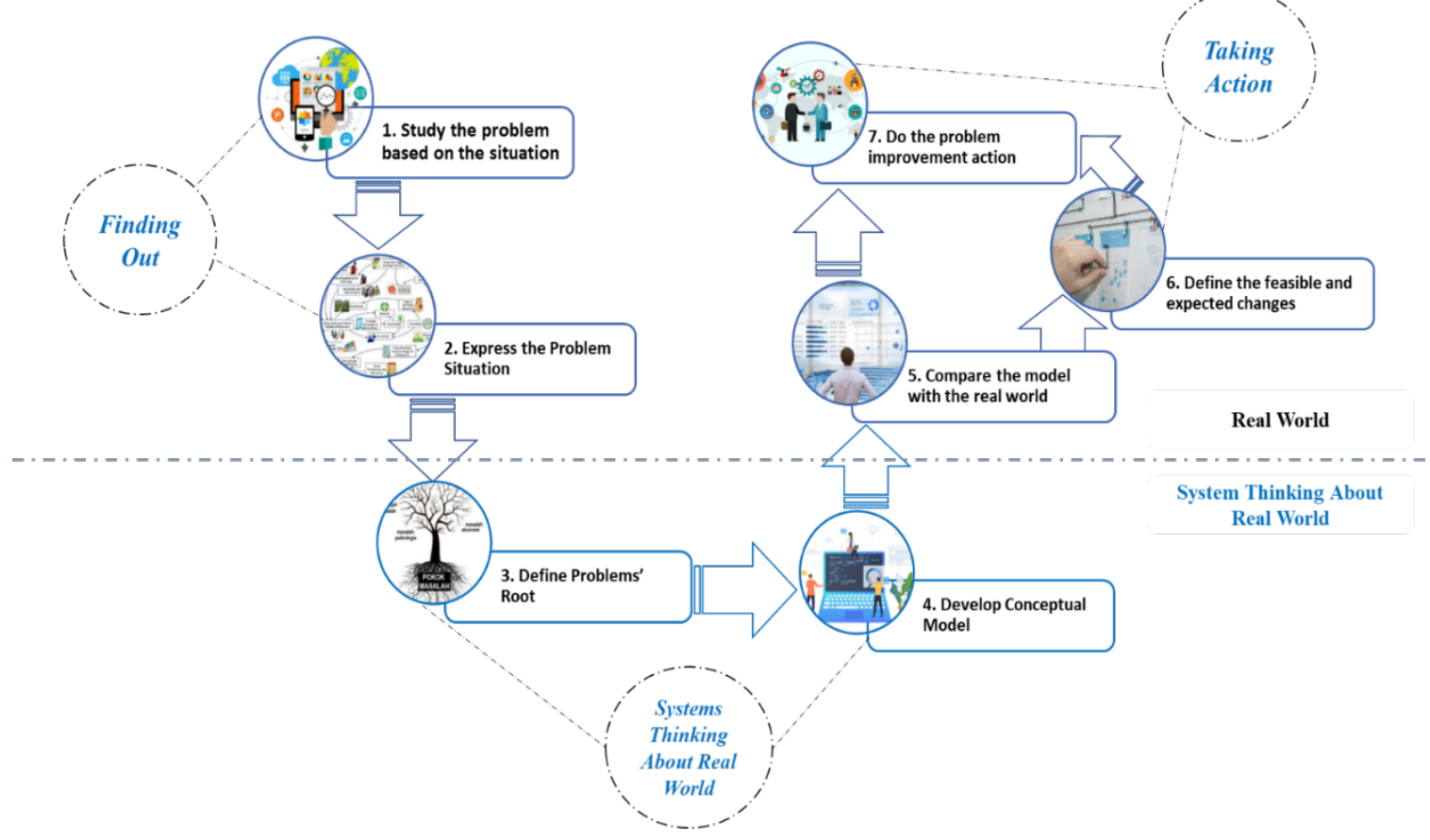

2: Steps of soft system methodology

I: CATWOE elements and description

\begin{tabular}{ll}
\hline \multicolumn{1}{c}{ Element of CATWOE } & \multicolumn{1}{c}{ Description } \\
\hline Customer & Who will benefit from the goal activity? \\
Actors & Who will carry out the activity? \\
Transformation & What must change for the input to become output? \\
World-view & What perspective makes the system meaningful? \\
Owners & Who can stop the activities? \\
Environmental & What constraints exist in the system environment? \\
\hline
\end{tabular}

Adopted from Checkland and Poulter (2010) 
forests in the future. According to Nurrochmat (2005), Indonesia's forest administrative governance significantly continues to change along with the shift of centralized forest management into decentralized forest management. Decentralized management itself is expected to be able to optimize the distribution of resources to help impoverished society, to improve more effective and responsive services, to increase local community accountability and participation in the process of decision making and also to give the opportunity to the regional government to manage the forest resources following the regional characteristics (Ekawati et al., 2014).

To date, there is no applicative model for good forest governance in Indonesia that can be used as a reference. Even though good governance elements can be identified and are the same for several contexts, good governance is actually specific to the value, structure of government, and society (Ekawati et al., 2014). Forest governance is guidance used by a group of people, stakeholders, and formal or informal institutions to obtain and use an authority in the management of forest resources to become sustainable and able to enhance the quality of life and livelihood of the community that is dependent on this sector (World Bank, 2009). Moreover, FAO (2009) defined forest governance as a way of act where the staff and the institution obtain and apply the authority in the management of forest resources.

One of the main problems of forest management in Indonesia is the weak forest management instruments, such as the absence of comprehensive laws and regulations in regulating the institution of forest and forest area management, which become one of the main causes of a number of forestry problems in Indonesia to generate (Ruhimat, 2010; YSWJ, 2017). This will also affect the management system of production forest; the weak instruments of forest management will directly affect the high amount of forest production cost that has to be expended by the company utilizing the timber forest product. According to Hakim (2009) forest management requires various operational costs, such as plantation, maintenance, controlling and securing forest from encroachment, fulfilling the state's obligation, fulfilling the obligation to a social environment, and other costs. From all expenses required, the cost for plantation is the expense with the highest percentage (35-45\%), followed by the cost of maintenance, construction of facilities and infrastructures, and forest security and monitoring. The same was also expressed by Hajrah et al. (2015); one of the most burdensome expenditures for the company utilizing forest products is the amount of monitoring cost that must be regularly expended. The high monitoring cost can cause ineffectiveness in the company's performance.

Findings on the field showed that a company utilizing forest products in Peusangan requires very high cost in plantation, which includes seedling/nursery cost, plantation, and land preparation. The high cost of seedling/nursery is because the company purchases the tree seedlings that are imported from other regions, although the seedlings are not necessarily suitable to the land specification. Besides, the company also has to expend monitoring and security costs in a large amount. In production forest management, the company does not employ the local community around the forest as business partners, which affects the high production cost they have to expend. Another negative impact of the lack of participation of community living around the forest in the process of forest management is the declined economy of the community in and around the forest, so that it will have an impact on the low level of prosperity of the community around the forest. This indicates that the production forest has not been optimally functioning in the community's economic development who lives around the forest (Ruhimat, 2010; Andrasmoro and Nurekawati, 2017).

\section{Problem Mapping}

The problems of the silvicultural model for production forest in Aceh Province are problems that are complex and related to each other. To simplify the understanding, the problems are presented in a rich picture. A rich picture is formed from the study result in the previous step to show the thorough view from various activities in the silvicultural system for production forest. This rich picture can also show the structure, process, relationship, conflict and uncertainty, and the problem. According to Checkland and Poulter (2010), the researcher can freely visualize the problematic situation with pictures, lines, or symbols. A rich picture of the problematic situation can be seen in Fig. 3.

The rich picture above visualizes the problem in the silvicultural model for production forest in Aceh Province. To date, the model for production forest management applied by the company requires very high cost in its production process. One of the causes is the lack of participation of the community around the forest in forest management. Necessarily, the community around the forest that are members of the forest farmer group has a significant role in reducing the forest production cost. But oftentimes, the corporate does not empower the resources available in the community around the forest that become members in the forest farmer group in the production activity, either in the forest monitoring and security or in the plantation process, such as procurement of seedlings and other activities. Those activities are activities that require high costs in the production process. If the company continues to let this happens, it is possible for the company to suffer bankruptcy. The same was also expressed by Suparna (2017) which stated that one of the main factors that cause the IUPHHK business activity to stop operating is the production cost that is high and continues to increase. The other factors are the 


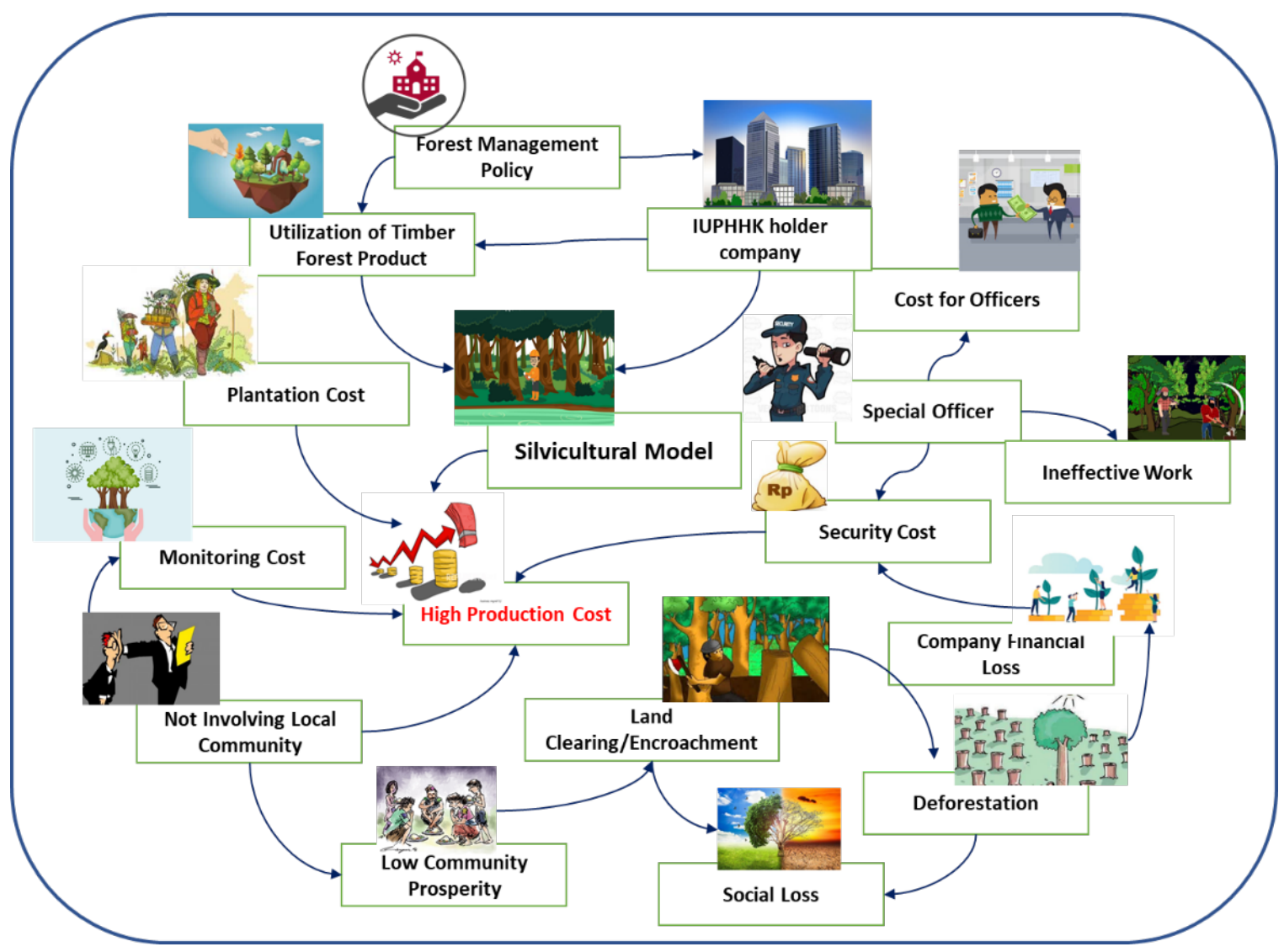

3: Rich Picture of Problems

relatively stagnant selling price of Roundwood, the problematic working area, and the forest potential that declines.

\section{Root Definition}

Management of production forest with IUPHHK system that has been running has generated various problems, either a social problem with the community around the forest, environmental degradation or problem of the continuity of production business the company itself (Yasman et al., 2013). Without an improvement in the existing management system, it is feared that worse deforestation will occur in the future, also the cessation of IUPHHK business operation. Root definition is a way to describe the system in the process of system modeling that being developed. The arrangement of root definition itself uses equation PQR, which is: do P, by $\mathrm{Q}$, in order to help achieve $\mathrm{R}$ (Check land and Poulter, 2010). In this studied problem, the system does activities of achieving development of a lowcost silvicultural model for production forest $(\mathrm{P})$ by using the implementation of various strategies that are effective and efficient by involving various parties (Q) in order to create a low-cost silvicultural model for production forest that is synergic, integrated, and sustainable (R). To describe how the development process of a low-cost silvicultural model for production forest was, this part will elaborate the relationship of the problems according to the importance of each element or institution that are involved in the system. CATWOE table is used to describe the process performed (Tab. II).

\section{Conceptual Model}

The conceptual model based on the result of root definition was then identified to obtain a series of activity processes in the low-cost silvicultural system for production forest. The conceptual model can be defined as something to describe the relationship of various activities and the role of the actors in the system to achieve their common goals (Papilo and Maarif, 2015). Basically, the problem of high production cost in the silvicultural model for production forest that has been applied by the IUPHHK-holder company is caused by the lack of participation and role of the community around the forest in forest management. Besides, the production forest in Peusangan District has considerable potential resources either on its natural resources or human resource, in which there is still forest area that has not been utilized so that it has big potential to be developed in IUPHHK-HA (Natural Forest). Other than that, it also has human resources potential in the form of forest farmers group which is very active in the monitoring and utilizing forest product, for instance, Alue Simantoek farmers group that has been existed in that forest area. 


\section{Components}

Customer: the person that affects/is affected by the system
System definition of each component

Community around the production forest, forest farmer group, the IUPHHK-holder company, community or customary stakeholders (pawang glee, peutua seuneubok, LSM), regional government.

- Community around production forest: a community who lives around the forest and has the main livelihood from forest product.

- Forest farmer group: a group of people who live around the forest and has the main livelihood from forest product.

- The IUPHHK-holder company: a company/party that holds Business Permit for Timber Forest Products Utilization.

Actor: person and system role in an activity

- The community of customary stakeholders: an institution that leads and organizes the mores regarding the management and preservation of forest environment (forest clearing/agriculture in the mountain area).

- Government: the actor who contributes to connecting the community with the IUPHHK holder company.

Transformation: process and changes

- The developed strategy of development of low-cost silvicultural model for production forest that is synergic, integrated, and sustainable.

World -view: impact from The creation of a policy and intervention strategy that can make a low-cost silvicultural the system implementation model for production forest.

Owner: all parties

Community around the production forest, forest farmer group, the IUPHHK-holder company, community or customary stakeholders (pawang glee, peutua seuneubok, LSM), university/research institution, regional government.

Environment: an

The diverse skill quality and the lack of knowledge of some people around the forest environmental constraint regarding good forest management that meets the applicable regulations become that surrounds the system a difficulty for the IUPHHK-holder company in selecting and doing quality enhancement and the implication

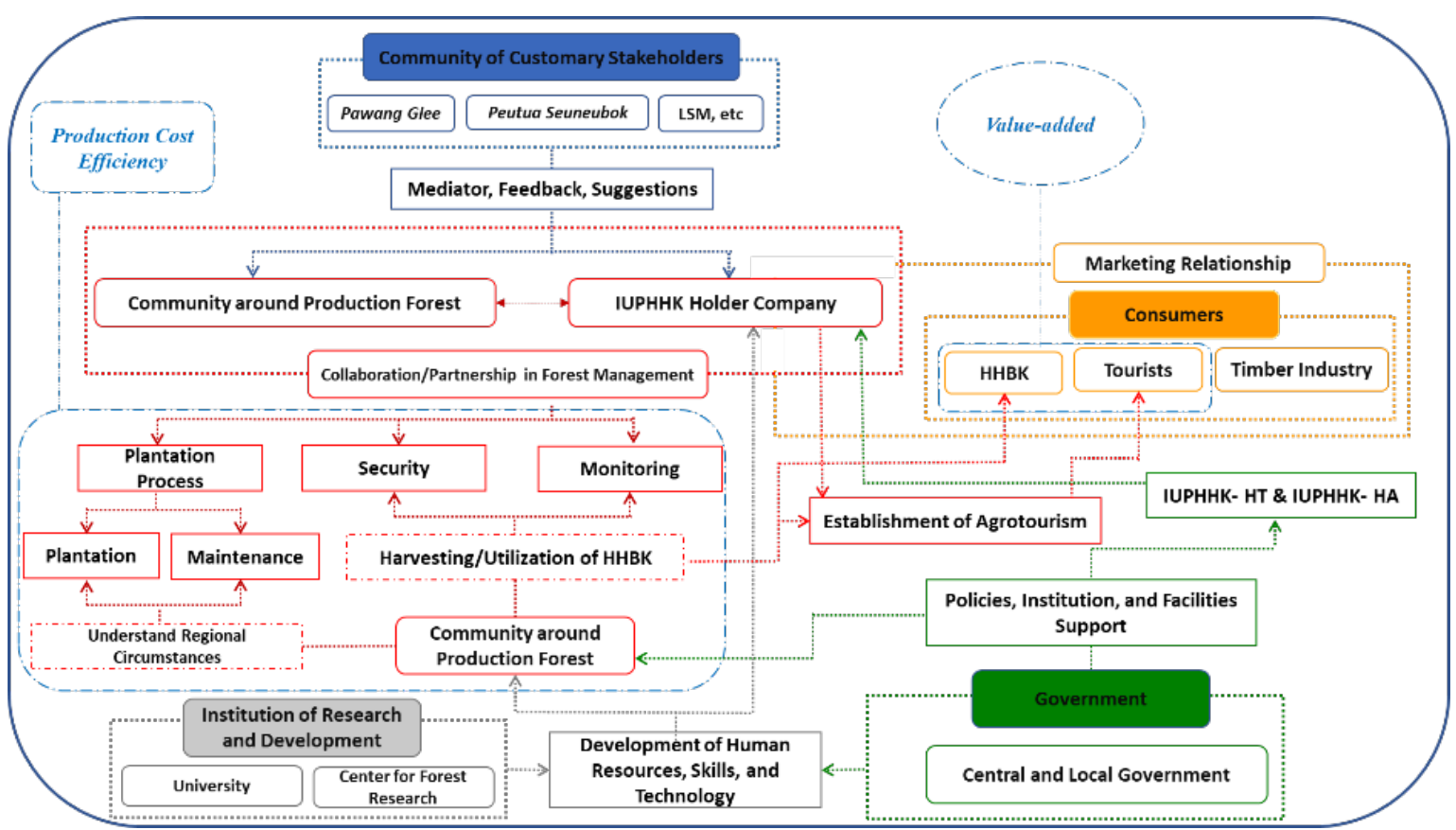

4: Low-cost Silvicultural Conceptual Model for Production Forest

Therefore, a conceptual model is necessary to bring together the interests of various parties in order to achieve the target of each involved party. According to Fadhil et al. (2017), the model formed in this step is the adaptive process, where each actor's activity happened and there is feedback between the process and the actors in the system. The developed conceptual model can be seen on Fig. 4. 


\section{Comparison Between Model and Real World}

After the conceptual model is obtained based on the established system design, it is necessary to compare the conceptual model with the real world. Comparing the model can be done through informal discussion, formal question and answer, making scenarios based on the model operation, or trying to imitate the real world's structure with the conceptual model (Checkland and Scholes 1990). The result of this comparison will generate a recommendation either in the form of model change, or keep going with the existing model, or model improvement. According to the analysis of experts' opinion, there were five recommendations given in this step, which are: 1) cost efficiency in the plantation process; 2) increase in the role of community around the forest and the forest farmer group in forest security and monitoring; 3) Empowerment of human resources of community around the forest and the forest farmer group through education, skill enhancement, and technology application (Tab. III).

\section{Plan of Changes}

Integrated and sustainable development is the development concept that keeps being encouraged to be evolved in all world development elements. One plan of world development that keeps being encouraged by the United Nations (UN) is the sustainable development plan or Sustainable Development Goals (SDGs) as a concept that underlies environmental management. The sustainable development concept is expected to be able to solve all problems such as poverty and famine, advancing health and education, and environmental conservation (United Nations, 2015). One of the main problems highlighted in the Sustainable Development Goals is the issue of forest management and its functions (Tanjung et al., 2017).

In the concept of sustainable development of production forest, community participation and involvement in the utilization of forest resources, also their participation in the monitoring and security are very important things to do to manifest forest sustainability, increase the prosperity of

III: Comparison of model with the real world

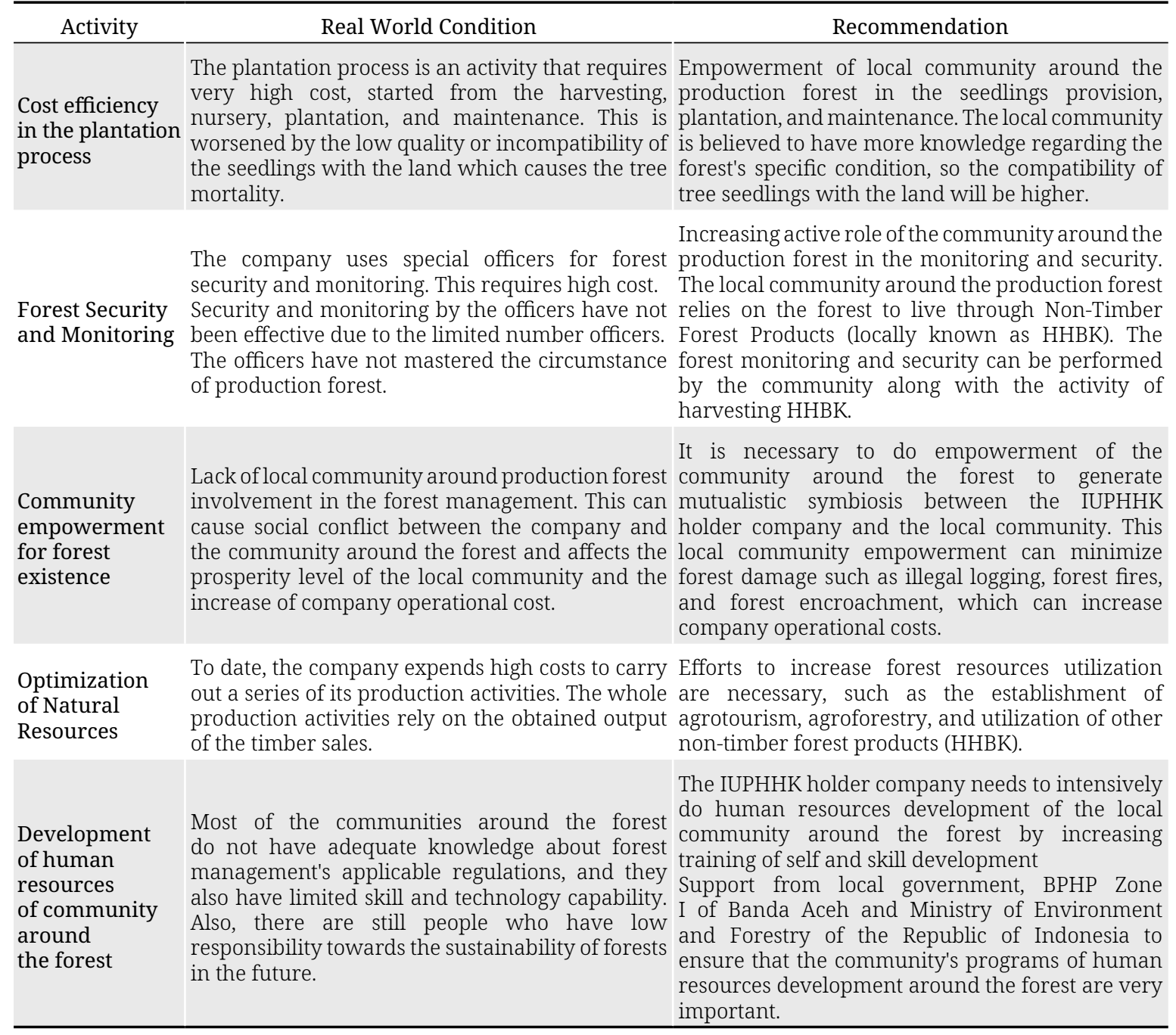


community around the forest, and the continuity of the production forest business itself (Gunawan et al., 2014) the involvement of community around the forest is a key feature of success in production forest management that can continuously give positive impact to the environment, company, and community. This positive impact can be in the form of efficiency in operational cost for several production activities, such as reducing the cost of forest fire and damage management, reducing the cost of maintenance, security, monitoring, and some other operational cost. These activities can be carried out by the people around the forest along with the activity of utilization or harvesting their own Non-Timber Forest Product (HHBK). Other than company operational cost efficiency, positive impacts can be in the form of an increase in the local community income, increase in forest environment sustainability, decrease in cases of illegal logging, forest fire, forest encroachment, and less empty land due to the active role of the community in cultivating the land and doing reforestation (Nasikh, 2009; Damayatanti, 2011; Ngabdani et al., 2015).

\section{Improvement Action}

The development of a silvicultural model for production forest is an activity that must be carried out in a sustainable and integrative manner by paying attention to various behaviors and environmental changes to create an effective and efficient silvicultural model. After going through several previous steps, this step did corrective formulation or improvement as the final step in the formulation of a model by generating several intervention strategies that can be applied by the stakeholders to achieve the system goals (Fig. 5). This strategy formulation will give a map of steps that are possible to be chosen with all the dynamics that may happen, so that it can solve the problem to achieve the goal (Harun and Dwiprabowo, 2014; Fadhil et al. 2017).

Based on Fig. 5, it can be seen that in the development of a silvicultural model for production forest, it is necessary to adopt a forest management system based on management collaboration in an effort to encourage the creation of a low-cost silvicultural model in the management of production forest in Aceh Province. In the implementation of this management collaboration system, two important elements become the focus of development: first, synergy and partnership between the community around the forest and the IUPHHK holder company in the management of production forest. Moreover, Harun and Dwiprabowo (2014) stated that synergy and partnership bring mutually beneficial positive impacts to both parties by sharing forest management roles and functions. The community around the forest can utilize the forest product potential, such as Non-Timber Forest Products (HHBK), to increase their economy; meanwhile, the company can make operation cost-efficient with the local community's involvement for several production activities, such as maintenance, monitoring, and security.

Second, it is necessary to do participatory enhancement from all involved parties in the production forest management system by involving all actors in forest product utilization. There are three main actor elements: government, IUPHHK holder company and the local community, and the

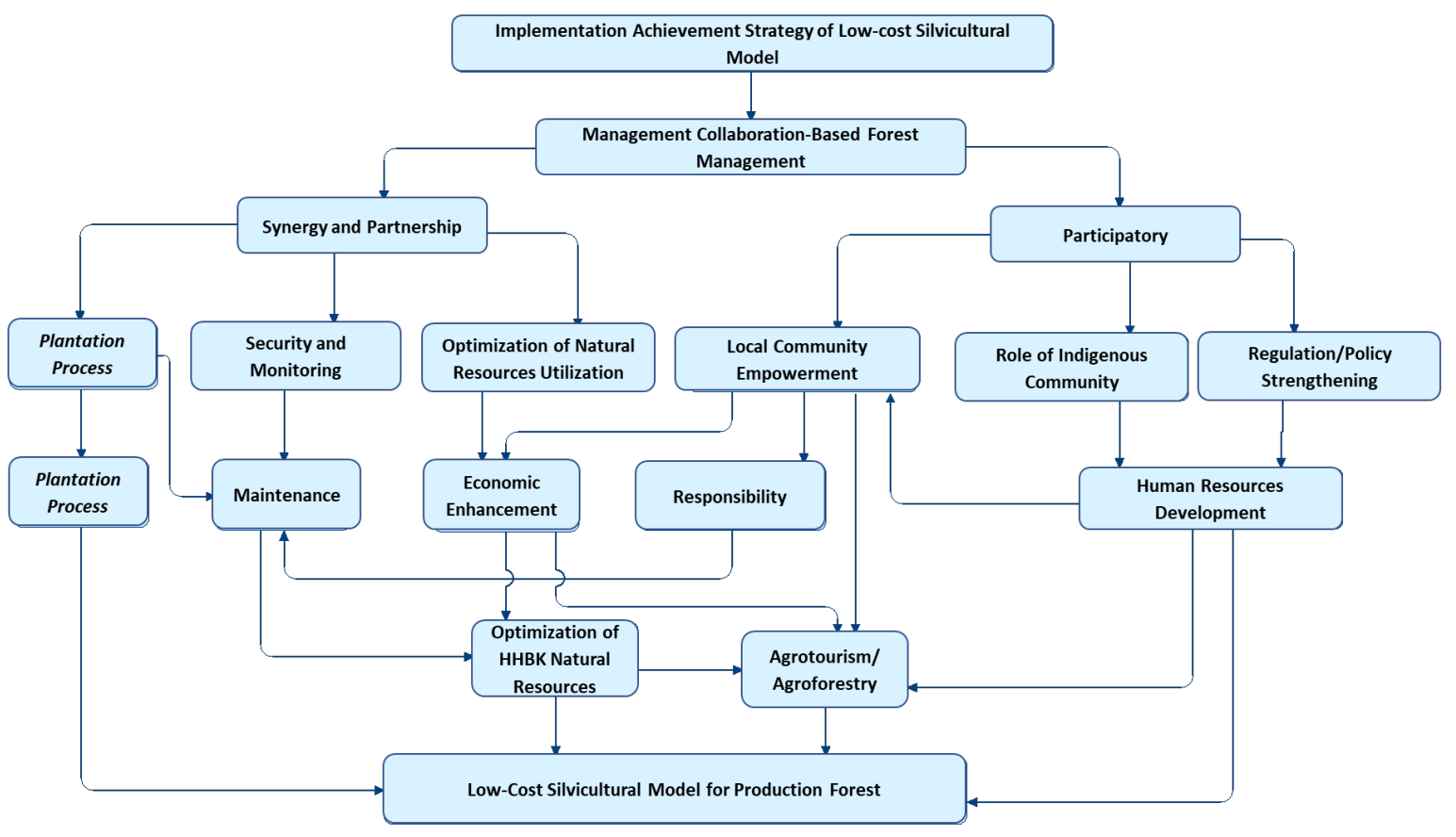

5: Development strategy of a low-cost silvicultural model for production forest 
community of customary stakeholders as supporting actors. Each party has a different duty, responsibility, and interest but must be able to be elaborated to achieve their common goals. Government has an important role in creating policies and regulations that concern all-parties, either the IUPHHK holder company or the community around the production forest. Besides, the local government is expected to encourage the community of customary stakeholders, such as pawang glee, peutua seuneubok, LSM, and other institutions, to actively participate in forest management and preservation. Furthermore, according to Azwir et al. (2017), they stated that this local community actively provides direct learning to the people around the forest to have the responsibility in managing the forest.

Program of community empowerment for the forest existence is very important to implement. This empowerment program is a concept of economic development by summarizing social values (Harun and Dwiprabowo, 2014). This empowerment can increase the economy and raise the dignity, socio-cultural values, and the responsibility of the local community towards the sustainability of the forest. This empowerment program must be accompanied by the improvement of skill, knowledge, and understanding regarding the forest governance that is good for the community around the forest (Widiyanto, et al., 2012). The presence of a community around the forest cannot be separated from the process of forest management. Forest management that involves the local community is believed to become an answer for every problem of forest management that has been happened. However, it is necessary to take efforts of self-development and skill for the community around the forest to synergize with the company to achieve their common goals (Andrasmoro and Nurekawati, 2017). In the process of development, changing habits or unifying various parties with different interests into one order is a difficult thing to do, but this process still has to be taken as an effort carried out in order to correct the flaws to become something better.

\section{CONCLUSION}

Community involvement is one factor that very much affects the success of sustainable forest management. The lack of community involvement in the management of production forest can result in the high operational cost of the IUPHHK holder company, the community's low prosperity level around the forest, and the high potential for deforestation to happen in the future. So far, there are two main strategies that can be played by the stakeholders in the development of a low-cost silvicultural model for production forest in Aceh Province, which are; synergy and partnership between the local community around the forest and the company that holds IUPHHK Peusangan, Bireuen Regency, Aceh Province, Indonesia in the management of production forest to carry out several activities, such as plantation, security, and monitoring. Then, participatory enhancement is also necessary from the main actors, which are government, IUPHHK-holder company, and the community, by carrying out their duty and responsibility according to their respective capability.

\section{REFERENCES}

ANDRASMORO, D. and NUREKAWATI, E. E. 2017. Analysis of community plantation forest policies development towards the increase in community prosperity in West Borneo, and Special Region of Yogyakarta [in Indonesian: Analisis pengembangan kebijakan hutan tanaman rakyat (HTR) terhadap peningkatan kesejahteraan masyarakat di Kalimantan Barat dan D.I Yogyakarta]. Jurnal Swarnabhumi, 2(1): 36-44.

ARIFANDY, M. I. and SIHALOHO, M. 2015. Effectiveness of Community Based Forest Management as Forest Resources Conflict Resolution [in Indonesian: Efektivitas Pengelolaan Hutan Bersama Masyarakat sebagai Resolusi Konflik Sumber Daya Hutan]. Sodality: Jurnal Sosiologi Pedesaan, 3(2): 147-158.

AZWIR, A., JALALUDDIN, J. and IBRAHIM, I. 2017. Community role in maintaining forest sustainability as source of life [in Indonesian: Peranan masyarakat dalam menjaga kelestarian hutan sebagai sumber kehidupan]. Jurnal Ekonomi Manajemen dan Akutansi, 3(1): 44-50.

BADAN PUSAT STATISTIK (BPS). 2016. Profile of Bireuen Regency [in Indonesian: Profil Kabupaten Bireuen]. Bireuen (ID).

BAHRUNI. 2011. Conduct study and Analysis on Economic Incentive Framework of SFM as Important option for Forest Based Climate Change Mitigation-to Reduce Emission from and by tropical forest. Jakarta: International Tropical Timber Organization.

BARBER, C. V., MATTHEWS, E., BROWN, D., BROWN, T. H., CURRAN, L. and PLUME, C. 2002. The State of the Forest: Indonesia. World Resources Institute. 
BATUBARA, S. C. 2016. Design of Sustainable Supply Chain System Management of Marine Capture Fishery Industry [in Indonesian: Disain sistem manajemen rantai pasokan industri perikanan tangkap laut berkelanjutan]. Dissertation Thesis. Bogor (ID): Institut Pertanian Bogor.

BERGVALL-KAREBORN, B. 2002. Qualifying Function in SSM Modeling - a case study. Systemic Practice and Action Research, 15(4), 309-330.

CHAZDON, R. L. and COE, F. G. 1999. Ethnobotany of woody species in second growth, old growth, and selectively logged forest of Noortheastern Costa Rica. Conserv. Biol, 13(6): 1312-1322.

CHECKLAND, P. 2013. Soft Systems Methodology. In: GASS, S. I. and FU, M. C. (Eds.). Encyclopedia of Operations Research and Management Science. Boston, MA: Springer.

CHECKLAND, P. and POULTER, J. 2010. Learning for action: a short definitive account of soft systems methodology, and its use for practitioners, teachers, and students. New York: Wiley.

CHECKLAND, P. and SCHOLES, J. 1990. Soft System Methodology in Action. England: John Wiley \& Sons Ltd.

DAMAYATANTI, P. T. 2011. Forest Conservation Efforts through Community Based Forest Resources Management [in Indonesia: Upaya Pelestarian HutanMelalui Pengelolaan Sumberdaya Hutan Bersama Masyarakat]. Jurnal Komunitas, 2(1): 70-82.

DARMANTO. 2014. Governance in management of protected forest (A study by using Soft Systems Methodology) [in Indonesia: Tata kelola dalam pengelolaan hutan lindung (Suatu Kajian dengan menggunakan Soft Systems Methodology)]. Dissertation Thesis. Tangerang Selatan (ID): Universitas Terbuka.

DARUSMAN, D. and BAHRUNI. 2004. Economic Analysis of Sustainable Forest Management at Unit Management Level in Indonesia. ITTO Project No. PD 42/00/REV.1 (F). Jakarta: ITTO and APHI.

EKAWATI, S., DWIPRABOWO, H., HARUN, M. K., HANDOYO, SALAKA, F. J., SUBEKTI, B. and RAHARJO, K. D. 2014. Synthesis of Integrative Research on Strengthening Forestry Governance [in Indonesian: Sintesis Penelitian Integratif Penguatan Tata Kelola Kehutanan]. Kementerian Lingkungan Hidup dan Kehutanan, Badan Penelitian dan Pengembangan Kehutanan, Pusat Litbang Perubahan Iklim dan Kebijakan.

FADHIL, R., MAARIF, M. S., BANTACUT, T. and HERMAWAN, A. 2017. Human resource development strategy for Gayo coffee agroindustry in the ASEAN economic community [in Indonesian: Model strategi pengembangan sumber daya manusia agroindustri kopi Gayo dalam menghadapi masyarakat ekonomi ASEAN]. Jurnal Manajemen Teknologi, 16(2), 141-155.

FADHIL, R., QANYTAH, Q., HASTATI, D. Y. and MAARIF, M. S. 2018. Development Strategy for a Quality Management System of Gayo Coffee Agro-Industry Using Soft Systems Methodology. Periodica Polytechnica Social and Management Sciences, 26(2): 168-178.

FAKHRURRAZI. 2018. Analysis of Cacao Agroindustry Based Agrotourism Development in Pidie Jaya Regency Aceh Province [in Indonesian: Analisis Pengembangan Agrowisata Berbasis Agroindustri Kakao di Kabupaten Pidie Jaya Provinsi Aceh]. Thesis. Bogor (ID): Institut Pertanian Bogor.

FEARNSIDE, P. M. and GUIMARES, W. M. 1996. Carbon uptake by secondary forest in Brazilian Amazonia. For. Ecol. Management, 80(1-3): 35-46.

GUNAWAN, K. S., BARKEY, R. A. and HAJAR, M. A. I. 2014. Program Implementation of Forest Community Resource Management in Perspective Village Community Development [in Indonesian: Implementasi Program Pengelolaan Sumberdaya Hutan Bersama Masyarakat dalam Perspektif Pemberdayaan Desa Hutan]. Program Pasca Universitas Hasanuddin.

HAJRAH, KARTODIHARDJO, H. and NUGROHO, B. 2015. Effectiveness of log tester technical personnel in the administration of forest products (study of natural forest case in Central Borneo [in Indonesian: Efektivitas tenaga teknis penguji kayu bulat dalam penatausahaan hasil hutan di Borneo (studi kasus hutan alam Kalimantan Tengah)). Risalah Kebijakan Pertanian dan Lingkungan, 2(3): 191-201.

HAKIM, I. 2009. The Study of Financing for Industrial Plantation Forest [in Indonesia: Kajian pembiayaan pembangunan hutan tanaman Industri. Jurnal Penelitian Sosial dan Ekonomi Kehutanan, 6(2): 135-158.

HARUN, M. and DWIPRABOWO, H. 2014. Resolution model of land conflict in Banjar production forest management unit model [in Indonesian: Model resolusi konflik lahan di kesatuan pemangkuan hutan produksi model Banjar]. JURNAL Penelitian Sosial dan Ekonomi Kehutanan, 11(4): 265-280.

HEART OF BORNEO (HB). 2014. Sustainable Forest Management [in Indonesian: Pengelolaan Hutan Lestari].HeartofBorneo.[Online].Availableat:http//heartofborneo.or.id/id/sustainabledevelopment/ detail/8/pengelolaan-hutan-lestari-phl [Accessed: 2014, December 15].

HIDAYAH, A. 2012. Conflict Management of Community Based Forest Resources Management (Case study: Concept of PHBM at KPH of Randublatung, Blora Regency, Province of Central Java [in Indonesian: 
Manajemen Konflik Pengelolaan Sumber Daya Hutan Berbasis Komunitas (Studi Kasus: Konsep PHBM di KPH Randublatung, Kabupaten Blora, Provinsi Jawa Tengah)]. Bogor (ID): Institut Pertanian Bogor.

MARGITAWATY, B. 2004. Phenomenon of Exchange in Collaborative Forest Management (Case study: Implementation of PHBM in Puncak Village Cigugur District and Linggasana Village Cilimus District Kuningan Regency Province of West Java) [in Indonesian: Fenomena Pertukaran dalam Pengelolaan Hutan Secara Kolaboratif (Studi Kasus: Implementasi PHBM di Desa Puncak Kecamatan Cigugur dan Desa Linggasana Kecamatan Cilimus Kabupaten Kuningan Provinsi Jawa Barat)] Bogor (ID): Institut Pertanian Bogor.

MARTIN, E. 2008. Application of soft system methodology for management of conflict-prone forest areas: case of Benakat research forest, South Sumatera) [in Indonesian: Aplikasi metodologi sistem lunak untuk pengelolaan kawasan hutan rawan konflik: kasus hutan penelitian Benakat, Sumatera Selatan]. Dissertation Thesis. Bogor (ID): Institut Pertanian Bogor.

NASIKH. 2009. Community Participation in the Forest Management at Forest and Land Rehabilitation Activities (Gerhan) Pasuruan East Java [in Indonesian: Partisipasi Masyarakat pada Pengelolaan Hutan di Kawasan Gerakan Rehabilitasi Hutan dan Lahan (Gerhan) Pasuruan Jawa Timur]. Jurnal Masyarakat Kebudayaan dan Politik, 22(2): 33-45.

NGABDANI, M., MURYANI, C. and SUDARYANTO, R. 2015. Community Participation in the Implementation of Community Based Forest Management (PHBM) Program in Desa Girimulyo Jogorogo District Ngawi Regency [in Indonesian: Partisipasi Masyarakat dalam Pelaksanaan Program Pengelolaan Hutan Bersama Masyarakat (PHBM) di Desa Girimulyo Kecamatan Jogorogo Kabupaten Ngawi]. Jurnal GeoEco, 1(1): 58-66.

NOVAYANTI, W. D., BANUWA, I. S., SAFE'I, R., WULANDARI, C. and FEBRYANO, I. G. 2017. Analysis of Factors Affecting Community Perception in Community Plantation Forest Development at KPH of Gedong [in Indonesian: Analisis Faktor-Faktor yang Mempengaruhi Persepsi Masyarakat dalam Pembangunan Hutan Tanaman Rakyat pada KPH Gedong]. Jurnal Hutan dan Masyarakat, 9(2): 61-74.

NUGRAHA, A. 2004. Welcoming Changes Towards Forestry Sector Revitalization [in Indonesian: Menyongsong Perubahan Menuju Revitalisasi Sektor Kehutanan]. Tangerang: Penerbit Wana Aksara.

NURROCHMAT, D. R. 2005. The Impacts of Regional Autonomy on Political Dynamics, Socio-Economics and Forest Degradation. Case of Jambi-Indonesia. Goettingen: Cuvillier Verlag.

PAPILO, P. and MAARIF, M. S. 2015. Policy Model of Bioenergy Agroindustry Management in the Perspective of Environmental Sustainability (Soft Systems Methodology as an Approach) [in Indonesian: Model Kebijakan Pengelolaan Agroindustri Bioenergi dalam Perspektif Kelestarian Lingkungan (Soft Systems Methodology sebagai Suatu Pendekatan)]. Jurnal PASTI, 9(1): 10-18.

PAYUGALLO, M. S. 2010. Diameter growth distribution model of Meranti tree in the selective cutting and line planting silvicultural system (case study: case at IUPHHK of PT. Erna Djuliawati Central Borneo [in Indonesian: Model distribusi pertumbuhan diameter tanaman meranti pada sistem silvikultur tebang pilih tanam jalur (studi kasus di IUPHHK PT. Erna Djuliawati. Kalimantan tengah)]. Bogor (ID): Institut Pertanian Bogor.

PITRI, R. M. N. 2012. Financial Incentive of Sustainable Natural Production Forest Management from Scheme of REDD+ Carbon Trading [in Indonesia: Insentif finansial pengelolaan hutan alam produksi lestari dari perdagangan karbon skema REDD+]. Thesis. Bogor (ID): Institut Pertanian Bogor.

RUHIMAT, I. S. 2010. Implementation of Forest Management Unit (KPH) Policies in Banjar Regency [in Indonesian: Implementasi kebijakan kesatuan pengelolaan hutan (KPH) Di Kabupaten Banjar]. Jurnal Analisis Kebijakan Kehutanan 7(3): 169-178.

SOLICHIN and RIYANTO, B. 2010. Measurement of Carbon in Production Forest Area through IHMB [in Indonesian: Pengukuran Karbon di Kawasan Hutan Produksi melalui IHMB]. Available at: http:// forclime.org/merang/Pengukuran\%20Karbon\%20di\%20Kawasan\%20IUPHHK.pdf [Accessed: 2021, July 20].

SUJARWO, W. and DARMA, I. D. P. 2011. Vegetation Analysis and Estimation of Carbon Stock in around Mountain and Lake Batur Kintamani Bali [in Indonesian: Analisis vegetasi dan pendugaan karbon tersimpan pada pohon di kawasan sekitar gunung dan danau Batur Kintamani Bali]. Jurnal Bumi Lestari, 11(1): 85-92.

SUPARNA, N. 2017. HPH role in maintaining the continuity of natural forest [in Indonesian: Peran HPH dalam menjaga keberlanjutan hutan alam]. Lestari Paper No. 03. USAID.

SUWARDI, A. B., MUKHTAR, E. and SYAMSUARDI. 2013. Species Composition and Carbon Stock in Tropical Lowland Forest, Ulu Gadut, West Sumatra [in Indonesian: Komposisi jenis dan cadangan karbon di hutan tropis dataran rendah, Ulu Gadut, Sumatera Barat]. Berita Biologi, 12(2): 169-176.

TANJUNG, N. S., SADONO, D. and WIBOWO, C. T. 2017. Community Participation Rate in Nagari Forest Management in West Sumatera [in Indonesian: Tingkat Partisipasi Masyarakat dalam Pengelolaan Hutan Nagari di Sumatera Barat]. Jurnal Penyuluhan, 13(1): 14-30. 
UNITED NATIONS. 2015. Sustainable Development Goals. [Online]. Available at: https:// sustainabledevelopment.un.org/topics [Accessed: 2021, July 20].

WIDIYANTO, J., HAIRUL BASRI, H. and DAHLAN. 2012. Potential and Strategy of Community Forest Development in Bireuen Regency Aceh Province [in Indonesian: Potensi dan strategi pengembangan hutan rakyat di Kabupaten Bireuen Provinsi Aceh. Jurnal Manajemen Sumberdaya Lahan, 1(1): 1-9.

WORLD BANK. 2009. Investing in A More Sustainable Indonesia. Country Environmental Analysis. Report No. 50762-ID. The World Bank.

WORLD BANK. 2009. Roots for Good Forest Outcomes: an Analytical Framework for Governance Reforms. Washington, DC: The World Bank.

YASMAN, I., NURROCHMAT, D., SEPTIANI, Y. and LASMINI. 2013. Role of Natural Production Forest Management in the Climate Change (REDD+, Sustainable Forest Management and RIL-C) [in Indonesian: Peran Pengelolaan Hutan Produksi Alam dalam Perubahan Iklim (REDD+, Pengelolaan Hutan Lestari dan $R I L-C)$ ]. The Nature Conservancy Program TERESTRIAL Indonesia.

YAYASAN SARANA WANA JAYA (YSWJ). 2017. Production Forest Management [in Indonesia: Pengelolaan Hutan Produksi]. Direktorat Kajian Strategis dan Kebijakan Pertanian Instut Pertanian Bogor dan Yayasan Sarana Wana Jaya. 
